\title{
CONTROVÉRSIAS MATERIAIS DO ENUNCIADO N. 13 DAS SÚMULAS VINCULANTES DO SUPREMO TRIBUNAL FEDERAL ${ }^{1}$
}

\section{MATERIALS CONTROVERSIES ABOUT BINDING PRECEDENTE N. 13 OF THE FEDERAL SUPREME COURT}

\section{Patrícia Brüggemann Rosa ${ }^{2}$}

Resumo: $O$ presente trabalho tem por objetivo destacar aspectos controvertidos materiais que envolvem o sempre atual enunciado n. 13 das Súmulas Vinculantes de Supremo Tribunal Federal. Nessa senda, o exame foi inicialmente centralizado nos pontos basilares da implementação das Súmula Vinculante, voltando-se para o contexto histórico e a necessidade da reforma do Judiciário que deu ensejo à promulgação da Emenda Constitucional n. 45, com a qual se inseriu o instituto no ordenamento pátrio. Firmados esses alicerces, passou-se a explorar o enunciado em voga, que tratado nepotismo na máquina pública, e, assim, desvendar sua eficácia. Focou-se em controvérsias materiais que dificultam seu emprego, quais sejam, a noção de parentesco lá consignada, porque não coincidente com aquela adotada pelo Código Civil; a compreensão de "pessoa jurídica" que circunda a limitação, já que não há consenso quanto ao que representa a expressão, tampouco quando se configura o nepotismo cruzado, também não delimitado; e - a mais polêmica delas -, a aplicabilidade da vedação a cargos políticos. Enfim, por intermédio dos fundamentos teóricos levantados, encerra-se com a conclusão de que, sem negar a importância de se debater o tema destacado, o verbete não apresenta a clareza que dele se espera e, em consequência, não representa ou consolida entendimento judicial sobre a matéria, sobretudo porque demanda interpretação do aplicador, o que contraria frontalmente a razão de ser de enunciados vinculadores.

1 O presente trabalho foi desenvolvido a partir do Trabalho de Conclusão de Curso em Direito pela Universidade Federal de Santa Catarina (UFSC).

2 Bacharela em Direito pela UFSC. Pós-graduanda em Direito Constitucional pela Universidade Anhanguera (Uniderp) em parceria com a Rede de Ensino Luiz Flávio Gomes (LFG). Assessora Jurídica em gabinete de Desembargador no Tribunal de Justiça de Santa Catarina (TJSC). E-mail: patibrug.@gmail.com 
Palavras-chave: Direito constitucional. Súmula vinculante. Nepotismo. Impessoalidade.

Abstract: The following study aims to highlight material controversial aspects that refer to the prevailing Binding Precedents No.13 statement of the Supreme Court. In this field of study, the analysis was initially focused on the cornerstone of the Binding Procedures implementation, turning itself to the historical context and the need for Judiciary reformulation that enabled the publication of Constitutional Amendment No.45, which introduced the Binding Precedents in the Brazilian Law system. Having established the baseline, the following step was to articulate the above mentioned statement which objective is to deal with nepotism in public administration, and by doing so, unveil its effectiveness. The above mentioned study concentrated in the controversial facts that limit its usage, such as, the concept of kinship that differ from the ones in Civil Rights; the understanding about "legal entity" definition, once there is no consensus as to what is the expression, neither when it refers to "crossed nepotism"; and the applicability to political tenure, which is the most controversy of all. Ultimately, by the means of the addressed theoretical fundaments, the conclusion is that even considering the importance of debating the subject, the item does not present the expected transparency, and as a consequence, does not represent or even consolidate the judicial understanding on the matter, especially since it demands the judge to discern or interpret, a fact that confronts the very reason of being a Binding statement.

Keywords: Constitutional right. Binding precedents. Nepotism. Impersonality.

\section{INTRODUÇÃO}

O instituto da Súmula Vinculante, criado pela Emenda Constitucional n. 45, de 30 de dezembro de 2004, por si só, já provoca amplo debate na doutrina, principalmente no que diz respeito à sua natureza jurídica e à suposta afronta ao princípio da separação dos poderes.

Dentre os já editados enunciados, o de n. 13, por se basear não em dispositivos determinados mas em princípios extraídos da Constituição Federal mostra-se sempre atual e tem especial relevância no mundo jurídico na medida que direciona - ou até determina - a evolução do direito no tocante àquela matéria.

Após breve resgate do contexto histórico no qual se deu a promulgação da Emenda Constitucional n. 45, que inseriu as 
Súmulas Vinculantes no ordenamento pátrio, e sem perder de vista a importância jurídica dos verbetes, busca-se desvendar as controvérsias arraigadas ao enunciado n. 13, forte no fim da Súmula Vinculante de pacificar o entendimento do Supremo Tribunal Federal sobre determinada matéria, permitindo ao magistrado o uso do enunciado como fundamento de decisão, sem que sua aplicação exija dele esforço interpretativo.

O enunciado, além de inovar na abrangência do $3^{\circ}$ grau colateral do vínculo de parentesco afetivo, não definiu o universo em que compreendida a noção de nepotismo cruzado e sequer esclareceu o termo "mesma pessoa jurídica" nele constante. Outrossim e mais essencial: não há instrução quanto à aplicação da vedação do nepotismo aos agentes políticos.

É o elementar: desvendar as controvérsias que envolvem a questão do nepotismo após a publicação da Súmula Vinculante que lhe diz respeito pelo Supremo Tribunal Federal.

\section{BREVE RESGATE HISTÓRICO DA CRIAÇÃO DO INSTITUTO DAS SÚMULAS VINCULANTES}

As súmulas vinculantes foram inseridas no ordenamento pátrio por meio da Emenda Constitucional n. 45, de 30 de dezembro de 2004, que, em um cenário em que o Judiciário enfrentava a crise de se deparar com a impossibilidade de julgar tantos processos (e recursos) quantos eram ajuizados, acrescentou-se à Carta Magna o art. 103-A, autorizando a edição de súmulas vinculantes pelo Supremo Tribunal Federal.

A adoção de entendimentos vinculantes em um sistema judicial tradicionalmente positivado, não se deu maneira isolada, mas em meio a um movimento que buscava resgatar o Judiciário da crise em que estava imergido. Tanto é que, longe de ser a única - ou mesmo principal - mudança no Judiciário, foi 
criada em conjunto à ampliação da competência da Justiça do Trabalho, e instituição do Conselho Nacional de Justiça (CNJ) e do Conselho Nacional do Ministério Público (CNMP).

O Projeto que deu origem à Emenda Constitucional n. 45, de 30 de dezembro de 2004, já era processado havia mais de uma década, a partir do Projeto de Emenda Constitucional n. 96 de 1992, de autoria do deputado Hélio Bicudo, apresentada em um cenário de clamor popular por mudanças capazes de solucionar a crise de um Judiciário mergulhado em dezenas de milhares de causas repetitivas, sobretudo ensejadas pela abundância de recursos e pela intransigência da Fazenda Pública (DANTAS, 2008, p. 180).

É claro que, como não poderia deixar de ser, a proposta exposta naquela oportunidade progrediu muito nos mais de doze anos de sua tramitação. Aliás, nela nem sequer constava a inclusão do objeto do presente trabalho, cuja inserção foi proposta apenas em 1993-94, pelo então relator Nelson Jobim.

O longo lapso temporal entre a proposta original e a publicação da Emenda Constitucional não tirou da justificativa elaborada pelo deputado-autor seu alto grau de atualidade. Nem mesmo hoje, após mais de vinte anos, poder-se-ia dizer ultrapassado o discurso, como se vê:

A timidez com que o governo brasileiro vem atendendo a necessidade de modernização de nosso aparelhamento judiciário tem sido, sem dúvida, a causa da crise avassaladora em que há muitos anos se esbate a nossa Justiça. Quase sempre tardia deixa que esta se embarace na inabilidade e incompetência das partes, e sofre hoje, mais do que nunca, o impacto arbitrário do Poder, representado por seus órgãos de segurança, que não vacilam em usar de prepotência, negligenciando conscientemente todo o elenco dos direitos humanos. Desprovidos de garantias, são poucos, muito poucos os que não cruzam os braços, à espera de que acabe a avalanche.Ora, a administração da Justiça é problema que a todos interessa. 
Não basta que o Legislativo elabore as leis e o Executivo as sancione. É preciso que o Judiciário assegure a sua execução em cada caso concreto. A norma jurídica só ganha corpo e produz efeitos quando fielmente aplicada. É através dos julgados que os direitos se tornam incontestáveis e a vontade de seus titulares se apresenta em forma coercitiva. As decisões dos juízes e tribunais são, portanto, a última etapa da vida do Direito. Com propriedade, diz Carlos Medeiros da Silva que, "sem um funcionamento adequado da organização judiciária, o país caminharia para a desordem e a descrença nas suas instituições".

Após doze anos de tramitação, aprovou-se, finalmente, a Emenda Constitucional n. 45, acrescentando-se, dentre tantas medidas, o art. 103-A à Constituição Federal, in verbis:

Art. 103-A. O Supremo Tribunal Federal poderá, de ofício ou por provocação, mediante decisão de dois terços dos seus membros, após reiteradas decisões sobre matéria constitucional, aprovar súmula que, a partir de sua publicação na imprensa oficial, terá efeito vinculante em relação aos demais órgãos do Poder Judiciário e à administração pública direta e indireta, nas esferas federal, estadual e municipal, bem como proceder à sua revisão ou cancelamento, na forma estabelecida em lei.

E os parágrafos:

$\S 1^{\circ}$ A súmula terá por objetivo a validade, a interpretação e a eficácia de normas determinadas, acerca das quais haja controvérsia atual entre órgãos judiciários ou entre esses e a administração pública que acarrete grave insegurança jurídica e relevante multiplicação de processos sobre questão idêntica.

$\S 2^{\circ}$ Sem prejuízo do que vier a ser estabelecido em lei, a aprovação, revisão ou cancelamento de súmula poderá ser provocada por aqueles que podem propor a ação direta de inconstitucionalidade.

$\S 3^{\circ}$ Do ato administrativo ou decisão judicial que contrariar a súmula aplicável ou que indevidamente a aplicar, caberá reclamação ao Supremo Tribunal Federal que, julgando-a 
procedente, anulará o ato administrativo ou cassará a decisão judicial reclamada, e determinará que outra seja proferida com ou sem a aplicação da súmula, conforme o caso.

Se o efeito vinculante - influência inegável do Common Law - foi recebido como novidade, o mesmo não se pode dizer da Súmula em si, cuja origem remonta aos chamados "assentos" do direito português. Como esclarece Streck (1998, p. 93) tratava-se exatamente da ideia de uniformização da jurisprudência, através de um ato do Poder Judiciário que dava à lei uma interpretação própria. Não se analisava um caso concreto, mas se assentava o entendimento de determinada lei quando da ocorrência de divergências judiciais.

O que levou o Supremo a instituir as súmulas foi a proliferação de demandas idênticas, sobretudo na Justiça Federal. A solução, porém, não foi capaz de frear o crescente número de processos e, até a atribuição do caráter vinculativo para os tribunais e Administração Pública, multiplicou-se em vinte vezes a quantidade de julgamentos por ano, que, em 1964, era de sete mil (SIFUENTES, 2005, p. 258).

É certo que a principal razão da adoção das súmulas vinculantes em nosso ordenamento é a busca de maior celeridade na resolução dos conflitos, já que, dessa forma, é possível evitar a tramitação prolongada de processos cujos recursos são fundados em "teses muitas vezes obsoletas e manifestamente opostas à reiterada jurisprudência dos tribunais superiores, bem como em desatendimento ao princípio da celeridade processual, agora expressamente consagrado na CF (art. 5o, LXXVIII)" (MARTINS, 2005, p. 45).

Além da celeridade, também a segurança jurídica é melhor garantida com as súmulas vinculantes, por assegurar ao cidadão maior previsibilidade, confiança e estabilidade no sistema que lhe presta jurisdição. Desse modo, tendo as partes prog- 
nóstico do desfecho que teria uma causa na justiça, poderão, elas mesmas, resolver seus problemas sem acionar a máquina judicial ou, em não se podendo evitar, o fazendo sem o temor de ser surpreendido (FLORENCIO, 2011, p. 344).

Já ressaltava, contudo, o então Presidente do Supremo Tribunal Federal, Ministro Sepúlveda Pertence (1996, p. 10), muito antes da promulgação da reforma, que:

[...] não se prega que a súmula vinculante como uma solução mirífica, maravilhosa, para curar todos os males, para resolver todos os problemas e dificuldades do Judiciário", mas sua adoção mostra-se uma solução capaz de desafogar a máquina da "prática lamentável, mas profundamente arraigada em nossos costumes administrativos, de continuar insistindo em questões superadas, apenas para ganhar tempo.

\section{A EDIÇÃO DO ENUNCIADO N. 13 E AS CONTROVÉRSIAS MATERIAIS A ELE ARRAIGADAS}

Sob a perspectiva e os fundamentos que deram ensejo à criação das Sumulas Vinculantes, passa-se à análise daquela objeto deste estudo, ressalvando-se que não se busca, com o presente trabalho, o esgotamento das questões referentes ao enunciado -sobretudo porque não está em foco, aqui, o debate acerca da controvérsia formal que envolve sua edição ${ }^{3}$-, mas busca-se apontar os termos que precisam ser aclarados pelo Supremo Tribunal Federal a respeito da redação por seus ministros editada, a fim de que lhe possam conferir maior eficácia e resultado prático.

Pois bem. $\mathrm{O}$ verbete concentrou-se em impedir o nepotis-

3 Sobre o tema, é o comentário de Alice Barreto de Antonio (2009, p. 67): "Inexistindo norma jurídica determinada sobre a qual recaia controvérsia acerca da interpretação, validade e eficácia, não se configura hipótese ensejadora de Súmula Vinculante. Como já dito, o nepotismo não poderia ser objeto de Súmula Vinculante, mesmo havendo polêmica quanto a sua constitucionalidade." 
mo, que consiste "numa política para empregar parentes, privilegiar os laços de sangue ou de afinidade, fechando-se o preenchimento de cargos públicos em grupos familiares" (ARAKAKI; ORTIZ, 2011, p. 103).

O termo advém do latim, deriva do termo "nepote", que significa "sobrinho" ou "protegido", com o sufixo "ismo", que remete à ideia de "ato", "prática", e tem sua origem no costume papal de nomear sobrinhos e demais parentes para cargos administrativos na Igreja, nos séculos XV e XVI, enquanto os que não integravam a privilegiada categoria eram excluídos do acesso a tais funções. A prática foi trazida ao Brasil juntamente com a vinda da Corte portuguesa, entre os anos de 1808 e 1821 (OLIVEIRA, 2009, p. 15).

É possível verificar a evolução da prática que, se de início visava beneficiar parentes próximos, ampliou-se para também alcançar relações que não se configuram pelo vínculo familiar, criando-se, assim, três diferentes formas de nepotismo: o puro, o cruzado e o político, conforme define Empinotti (2013, p. 38):

Primeiro, o nepotismo puro, que é a nomeação de parentes para cargo em comissão, cujas funções serão exercidas sobre sua própria orientação hierárquica.Já o nepotismo cruzado é caracterizado, como bem definido por Diogenes Gasparini, pela nomeação recíproca de parentes de autoridades dentro da mesma instituição e, cujas funções serão exercidas pela orientação da autoridade nomeante, e não da beneficiada.A terceira espécie é o nepotismo político que, como o próprio nome já define, é a nomeação de pessoas, independente do vínculo de parentesco com a autoridade nomeante, é praticado pra cumprir acordos políticos.

Ainda que sob novos mantos, o nepotismo persiste - muito embora já não seja mais admitido pela legislação brasileira, porque contraria princípios como o da moralidade administrativa e o da impessoalidade.

Nessa senda, alertaAlmeida (2015, p. 101-102): 
Por mais que a pessoa nomeada ou investida em função de confiança, ou comissionada seja dotado de conhecimento técnico específico, a sua proximidade parental ou conjugal com o agente público a colocaria, de certa forma, em situação de suspeição, mesmo que não esteja ou não venha a ser beneficiada indevidamente. Nem se diga com relação àqueles sem conhecimento técnico necessário, que, em determinadas ocasiões, apenas ocupam suas funções para usufruírem das condições oferecidas pela Administração, sem oferecer qualquer eficiência à atividade pública.

O combate ao nepotismo, portanto, parte da força arraigada a tais princípios, que se mostram suficientes para coibir a prática, mesmo inexistente lei infraconstitucional uniforme que trate do tema (EMPINOTTI, 2013, p. 40), já que servem de orientação para interpretação de toda legislação do sistema jurídico a que se aplicam.

É o princípio da impessoalidade que determina que os cargos sejam providos a partir da aferição da necessária qualificação para a função, sem que com isso ocorra benefícios em razão de relacionamentos, parentescos ou amizades (CUNHA, 2010, p. 33).

No sentido, manifesta-se Mello (2015, p. 117):

Nele se traduz a ideia de que a Administração tem que tratar a todos os administrados sem discriminações, benéficas ou detrimentosas. Nem favoritismo nem perseguições são toleráveis. Simpatias ou animosidades pessoais, políticas ou ideológicas não podem interferir na atuação administrativa e muito menos os interesses sectários, de facções ou grupos de qualquer espécie. O princípio em causa não é senão o próprio princípio da igualdade ou isonomia. Está consagrado explicitamente no art. 37, caput, da Constituição. Além disso, assim como "todos são iguais perante a lei" (art. 5', caput), a fortiori teriam de sê-lo perante a Administração.

Já o princípio da moralidade, também balizador do combate ao nepotismo, apresenta-se como o dever de boa-admi- 
nistração. É o "direito subjetivo público a uma gestão proba e honesta, influenciado pela conversão instrumentalizada de outros princípios da Administração Pública (notadamente, os princípios da impessoalidade, lealdade, imparcialidade, publicidade, razoabilidade)" (CUNHA, 2010, p. 32).

Significa dizer que apenas a legalidade não basta, se não estiver acompanhada de valores éticos e morais, mesmo porque "nem tudo o que é legal é honesto, visto que, se de um lado é imprescindível a legalidade, de outro também os são a moralidade e os valores éticos para o bom desenvolvimento de qualquer atividade" (ARAKAKI; ORTIZ, 2011, p. 103).

Ainda, como ressaltou o Ministro Marco Aurélio de Mello, no julgamento do Recurso Extraordinário n. 160.381/SP, em 29-3-1994,o princípio da moralidade deflui de todo o ordenamento, sendo inclusive desnecessário para a exigência do seu cumprimento que figure expressamente no texto legislativo:

Poder-se-á dizer que apenas agora a Constituição Federal consagrou a moralidade como princípio de administração pública (art. 37 da Constituição Federal). Isso não é verdade. Os princípios podem estar ou não explicitados em normas. Normalmente, sequer constam de texto regrado. Defluem no todo do ordenamento jurídico. Encontram-se ínsitos, implícitos no sistema, permeando diversas normas regedoras de determinada matéria. O só fato de um princípio não figurar no texto constitucional, não significa que nunca teve relevância de princípio. A circunstância de, no texto constitucional anterior, não figurar o princípio da moralidade não significa que o administrador poderia agir de forma imoral ou mesmo amoral. [...] Os princípios gerias de direito existem por força própria, independentemente de figurarem em texto legislativo. E o fato de passarem a figurar em texto constitucional ou legal não lhes retira o caráter de princípio.

Forte nesses princípios, portanto, e a partir da Emenda Constitucional n. 45, que, além de possibilitar a edição de Súmulas Vinculantes pelo Supremo Tribunal Federal, inseriu no 
ordenamento jurídico pátrio o Conselho Nacional de Justiça, por meio do art. 103-B da Constituição Federal, imputando-lhe, dentre outras funções, a tarefa de zelar pela observância do art. $37^{4}$, como define a redação do $\S 4^{\circ}$, inciso II, do mencionado dispositivo ${ }^{5}$, foi editada a Resolução $\mathrm{n}$. 7, de 18-10-2005, do Conselho Nacional de Justiça, marco contra o nepotismo, que estabelece as hipóteses de ocorrência, em seu art. $2^{\circ}$, e veda a prática em todos os órgãos do Poder Judiciário:

Art. $2^{\circ}$ Constituem práticas de nepotismo, dentre outras:

I-o exercício de cargo de provimento em comissão ou de função gratificada, no âmbito da jurisdição de cada Tribunal ou Juízo, por cônjuge, companheiro ou parente em linha reta, colateral ou por afinidade, até o terceiro grau, inclusive, dos respectivos membros ou juízes vinculados;

II-o exercício, em Tribunais ou Juízos diversos, de cargos de provimento em comissão, ou de funções gratificadas, por cônjuges, companheiros ou parentes em linha reta, colateral ou por afinidade, até o terceiro grau, inclusive, de dois ou mais magistrados, ou de servidores investidos em cargos de direção ou de assessoramento, em circunstâncias que caracterizem ajuste para burlar a regra do inciso anterior mediante reciprocidade nas nomeações ou designações;

III-o exercício de cargo de provimento em comissão ou de função gratificada, no âmbito da jurisdição de cada Tribunal ou Juízo, por cônjuge, companheiro ou parente em linha reta, colateral ou por afinidade, até o terceiro grau, inclusive, de qualquer servidor investido em cargo de direção ou de assessoramento;

IV-a contratação por tempo determinado para atender a ne-

4 Art. 37. A administração pública direta e indireta de qualquer dos Poderes da União, dos Estados, do Distrito Federal e dos Municípios obedecerá aos princípios de legalidade, impessoalidade, moralidade, publicidade e eficiência [...]

$5 \S 4^{\circ}$ Compete ao Conselho o controle da atuação administrativa e financeira do Poder Judiciário e do cumprimento dos deveres funcionais dos juízes, cabendo-lhe, além de outras atribuições que lhe forem conferidas pelo Estatuto da Magistratura:[...]II-zelar pela observância do art. 37 e apreciar, de ofício ou mediante provocação, a legalidade dos atos administrativos praticados por membros ou órgãos do Poder Judiciário, podendo desconstituí-los, revê-los ou fixar prazo para que se adotem as providências necessárias ao exato cumprimento da lei, sem prejuízo da competência do Tribunal de Contas da União; 
cessidade temporária de excepcional interesse público, de cônjuge, companheiro ou parente em linha reta, colateral ou por afinidade, até o terceiro grau, inclusive, dos respectivos membros ou juízes vinculados, bem como de qualquer servidor investido em cargo de direção ou de assessoramento;

$\mathrm{V}$-a contratação, em casos excepcionais de dispensa ou inexigibilidade de licitação, de pessoa jurídica da qual sejam sócios cônjuge, companheiro ou parente em linha reta ou colateral até o terceiro grau, inclusive, dos respectivos membros ou juízes vinculados, ou servidor investido em cargo de direção e de assessoramento.

Como afirmam Arakaki e Ortiz(2011, p. 108), o que o Conselho Nacional de Justiça demonstrou, com a resolução, foi o comprometimento do Judiciário em depurar o nepotismo de suas próprias veias. A declaração de constitucionalidade, proferida pelo Supremo Tribunal Federal em 20-8-2008, no âmbito da Ação Direta de Constitucionalidade n. 12, ajuizada pela Associação dos Magistrados Brasileiros a fim de questioná-la ressaltou ainda mais o importante papel do CNJ.

Nesse cenário, entendendo o Supremo Tribunal Federal que a prática do nepotismo estaria em desacordo com os princípios da moralidade e da impessoalidade, foi editada pelo Supremo a Súmula Vinculante n. 13:

A nomeação de cônjuge, companheiro ou parente em li-
nha reta, colateral ou por afinidade, até o terceiro grau, in-
clusive, da autoridade nomeante ou de servidor da mesma
pessoa jurídica investido em cargo de direção, chefia ou
assessoramento, para o exercício de cargo em comissão ou
de confiança ou, ainda, de função gratificada na adminis-
tração pública direta e indireta em qualquer dos Poderes da
União, dos Estados, do Distrito Federal e dos Municípios,
compreendido o ajuste mediante designações recíprocas,
viola a Constituição Federal.

Balizando-se pelo art. $2^{\circ}$, da Lei n. 11.417, de 19-12-2006

6 Art. $2^{\circ} \mathrm{O}$ Supremo Tribunal Federal poderá, de ofício ou por provocação, após reiteradas 
a Súmula pôde irradiar os efeitos da Resolução do CNJ, para, como instrumento legítimo, abrangernão só o Poder Judiciário, como também os Poderes Executivo e Legislativo, o que, ressalta-se, "não quer dizer que o nepotismo era livre nestes, porém a sua proibição se lastreava numa interpretação principiológica" (ARAKAKI; ORTIZ, 2011, p. 109).

Além do papel inibidor, a Súmula pode propiciar ao magistrado, quando "instado a se manifestar diante de uma situação de nepotismo e que lhe compita apreciar, faça-o com supedâneo na súmula editada, sucintamente, sem a necessidade de maiores divagações doutrinarias e principiológicas." (ARAKAKI; ORTIZ, 2011, p.109).

Na prática, porém, não se mostra tão simples a aplicação do enunciado aos casos apresentados aos tribunais. É que a concisa e pouco específica redação gera dificuldades de interpretação (EMPINOTTI, 2013, p. 43), o que contraria não só a própria razão de existir do instituto da Súmula Vinculante, que é, a partir da determinação de qual interpretação normativa deve ser aplicada à certa matéria constitucional, dar segurança ao sistema jurídico, como o objetivo do enunciado n. 13, qual seja, dar solução ao nepotismo.

Ora, se foram as Súmulas Vinculantes inseridas na Constituição da República, por meio da Emenda Constitucional n. $45 / 2004$, justamente com o fito de pacificar controvérsias jurisprudenciais provenientes de reiteradas decisões do Supremo Tribunal Federal sobre determinada matéria (ANTONIO, 2009 , p. 65), é certo que devem contribuir para a solução de debates e não para agregar ainda mais incertezas aos temas.

No caso da Súmula Vinculante n. 13, as obscuridades nela

decisões sobre matéria constitucional, editar enunciado de súmula que, a partir de sua publicação na imprensa oficial, terá efeito vinculante em relação aos demais órgãos do Poder Judiciário e à administração pública direta e indireta, nas esferas federal, estadual e municipal, bem como proceder à sua revisão ou cancelamento, na forma prevista nesta Lei. 
constantes não permitem a indicação do apontamento exato do que é permitido ou não, sendo mister a interpretação tanto pelos atores do Direito quanto pela Administração Pública (MAGALHÃES, 2008, p. 1).

Da lição de Cunha (2010, p. 34), destaca-se:

Não há como aplicar a Súmula n. 13 sem a necessidade de realizar um esforço interpretativo, o que coloca novamente a matéria do nepotismo e suas implicações em seara de difícil compreensão e extensão, dificultando a orientação aos agentes públicos e o fim da prática nefasta. Ademais, Súmulas não devem carecer de interpretação para serem aplicadas.

A dificuldade de aplicação do enunciado reside em dois pontos controvertidos principais: a) o vínculo de parentesco; e b) os cargos e a extensão da súmula.

Em primeiro lugar, deve-se destacar que o enunciado, ao definir as hipóteses de ocorrência de nepotismo, para manter-se em sintonia com o critério adotado pelo Resolução do CNJ, ampliou a compreensão do vínculo de parentesco por afinidade que, pelo expresso no parágrafo único, do art. 1.595, do Código $\mathrm{Civil}^{7}$, estaria limitado, em linha colateral, ao segundo grau (MAGALHÃES, 2008, p. 2).

Entendem Arakaki eOrtiz (2011, p. 111) que "para os casos de nepotismo, utiliza-se o critério adotado pelo o STF; para as demais relações jurídicas, continua o critério que o próprio Código Civil adota".

Nesse viés reside a controvérsia a respeito do caráter perpétuodo vínculo afetivo em linha reta. Isso porque o parágrafo $2^{\circ}$, do art. 1.595, do Código Civil estabelece que "na linha reta, a afinidade não se extingue com a dissolução do casamento ou

7 Art. 1.595. Cada cônjuge ou companheiro é aliado aos parentes do outro pelo vínculo da afinidade. $\S 1 \underline{o} \mathrm{O}$ parentesco por afinidade limita-se aos ascendentes, aos descendentes e aos irmãos do cônjuge ou companheiro. 
da união estável”.

Da primeira análise, o caráter ad eternum da proibição é o que se verifica, mesmo se decorrido considerável lapso temporal. Há que se examinar o ponto, porém, com maior cautela. Como alerta Cunha(2010, p. 35), faz-se forçosa a aplicação dos princípios da razoabilidade e da proporcionalidade, "haja vista não haver razão de restar caracterizada incompatibilidade entre servidos em exercício de cargo em comissão ou confiança ou ainda função gratificada com pessoas que já não integram seu círculo familiar".

Recentemente, a Segunda Turma do Supremo Tribunal Federal, ao julgar a Reclamação n. 18.564/SP, em 23-2-2016, reconheceu que para a configuração de prática contrária ao enunciado é preciso a presunção de que a escolha de determinado agente para ocupar cargo de direção, chefia ou assessoramento decorra do potencial de interferência no processo de seleção de quem com ele tenha relação de parentesco. Do contrário, entendeu-se por haver, também, violação ao princípio da impessoalidade, ao vedar ao cidadão o acesso ao cargo pela simples existência de parentesco com quem nem sequer tem competência para selecioná-lo ou nomeá-lo (Informativo n. 815, de 4-3-2016).

Outra questão em que mister a interpretação da súmula por quem a aplique é quanto a sua extensão, que não resta clara a partir da leitura do enunciado, o que impõe a análise de inúmeros pontos até que resulte, efetivamente, na redação sumulada.

Em primeiro lugar, não há conclusão exata a se chegar com a expressão "mesma pessoa jurídica" constante da Súmula. Ao mesmo tempo que se pode dizer tratar do mesmo órgão específico, pertencente a uma das três esferas da Federação, também se entende que "um município, o Distrito Federal, um estado e a União, são pessoas jurídicas únicas, ou seja, englobam to- 
dos os seus entes, tornando-se uma pessoa jurídica complexa" (MAGALHÃES, 2008, p. 2).

Também a hipótese de nepotismo cruzado, que se caracteriza quando "há troca de favores entre agentes públicos, de forma que seus parentes sejam nomeados para cargos de confiança, impondo, pela via indireta, o favorecimento vedado pela probidade administrativa" (CUNHA, 2010, p. 31), exige ajustes. Não há certeza quanto ao âmbito da reciprocidade exigida para que se o configure: se necessária a ocorrência dentro do mesmo ente, ou se a simples troca de favor em qualquer das três esferas da Federação já caracteriza o nepotismo cruzado (MAGALHÃES, 2008, p. 2).

A dúvida mais polêmica, por fim, reside na possibilidade ou não de aplicação da vedação do nepotismo aos cargos políticos. Diz-se que o art.37 da Constituição Federal, no qual se baseia, fundamentalmente, a súmula em análise, refere-se a cargos e funções administrativas e não políticas e que esses possuem um vínculo diferenciado com a Administração, por isso não estariam sujeitos aos mesmos princípios que aqueles.

A propósito, é a definição de Mello (2012, p. 253-254) para agentes políticos:

Agentes políticos são os titulares dos cargos estruturais à organização política do país, ou seja, ocupantes dos que integram o arcabouço constitucional do Estado, o esquema fundamental do Poder. Daí que se constituem nos formadores da vontade superior do Estado. São agentes políticos apenas o Presidente da República, os Governadores, Prefeitos e respectivos vices, os auxiliares imediatos dos Chefes de Executivo, isto é, Ministros e Secretários das diversas Pastas, bem como os Senadores, Deputados federais e estaduais e os Vereadores.

Os tribunais têm entendido que o cargo político não se enquadra nos dito "em comissão" ou "confiança", previstos no 
enunciado, estando a súmula limitada àqueles estritamente administrativos. Aliás, esse é o posicionamento do próprio Supremo Tribunal Federal desde os precedentes que deram ensejo à Súmula Vinculante n. 13, como se extrai da ementa do Recurso Extraordinário n. 579.951/RN:

ADMINISTRAÇÃO PÚBLICA. VEDAÇÃO NEPOTISMO. NECESSIDADE DE LEI FORMAL. INEXIGIBILIDADE. PROIBIÇÃO QUE DECORRE DO ART. 37, CAPUT, DA CF. RE PROVIDO EM PARTE. I-Embora restrita ao âmbito do Judiciário, a Resolução 7/2005 do Conselho Nacional da Justiça, a prática do nepotismo nos demais Poderes é ilícita. II-A vedação do nepotismo não exige a edição de lei formal para coibir a prática. III-Proibição que decorre diretamente dos princípios contidos no art. 37, caput, da Constituição Federal. IV-Precedentes. VRE conhecido e parcialmente provido para anular a nomeação do servidor, aparentado com agente político, ocupante, de cargo em comissão (RE n. 579.951, Rel. Min. Ricardo Lewandowski, Tribunal Pleno, julgado em 20-8-2008, DJe de 24-10-2008).

Apesar do posicionamento, o que se extrai do corpo do acórdão não é, de forma alguma, a negligência em relação aos cargos políticos, já que, ainda que não abrangidos pela súmula (como confirmado por decisão posterior à sua edição ${ }^{8}$ ), também estão sujeitos aos princípios da impessoalidade e, sobretudo, da moralidade.

É do voto do Ministro Celso de Mello:

O fato é um só, Senhor Presidente: quem tem o poder e a força do Estado em suas mãos, não tem o direito de exercer, em seu próprio benefício, a autoridade que lhe é conferida pelas leis da República. O nepotismo, além de refletir um gesto ilegítimo de dominação patrimonial do Estado, desrespeita os postulados republicanos da igualdade, da impessoalidade e da moralidade administrativa. E esta Suprema Corte, Senhor 10-2008, DJe de 21-11-2008. 
Presidente, não pode permanecer indiferente a tão graves transgressões da ordem constitucional. Concluo o meu voto. E, ao fazê-lo, reafirmo o meu entendimento de que o nepotismo se mostra incompatível com o sistema constitucional, impondo-se, por isso mesmo, a vedação de sua prática a todos os Poderes da República e a todos os níveis em que se estrutura o Estado Federal brasileiro.

$\mathrm{Na}$ ocasião do julgamento mencionado, manifestou-se o Ministro Ricardo Lewandowski, relator do Recurso Extraordinário:

[...] cada caso concreto deverá ser avaliado à luz da proibição do nepotismo que emana do artigo 37, caput, um pouco na linha do que colocou a Ministra Cármen Lúcia. Eu fico com certo receio de assentarmos, com todas as letras, que, em se tratando de Secretário Municipal, que é um cargo político de livre nomeação, enfim, de confiança do prefeito, tal atitude seria lícita. Amanhã, se ele colocar a esposa em um "cargo chave" de Secretária de Governo, isso seria lítico à luz da proibição do nepotismo, do princípio da moralidade? Isso acontece no cotidiano deste grande Brasil.

Ao que respondeu a Ministra Cármen Lúcia que "não existe liberdade absoluta em lugar algum, senão o governante poderia escolher apenas os seus familiares para todos os cargos. E por ser cargo político, isso seria permitido? De modo algum".

Aqui vale o aparte de se desvelar que da desnecessidade de texto legislativo inibidor expresso decorre, inclusive, a competência do município, como entidade autônoma, para“estabelecer, por lei, outras hipóteses de vedação do nepotismo, na contratação de servidores públicos para cargos em comissão ou funções gratificadas, não se limitando aos termos da Súmula Vinculante no 13"(ALMEIDA, 2015, p. 119-120).

Acrescenta-se, ainda, a reserva de que proibição fria poderia gerar ainda maiores inconvenientes, que também foram ponderados quando da preparação da redação do enunciado 
vinculante:

É importante que o legislador municipal, antes de criar regras mais rígidas do que aquela fixada pela Súmula, leve em consideração a sua estrutura populacional. Nos pequenos municípios, principalmente, com relação àqueles localizados no interior do País, são comuns as grandes famílias, o que acaba por abranger parcelas significativas da comunidade ligada por algum grau de parentesco(ALMEIDA, 2015, p. 120).

O resultado da exclusão da referência aos cargos políticos na redação da Súmula é que remanesce a discussão e, por muitos Tribunais, há flexibilização do nepotismo nessa esfera. Inúmeros são os julgados em que se admitiu a nomeação de parentes (irmãos e cônjuges, principalmente) para cargos políticos para os quais não apresentavam qualquer conhecimento técnico, ao argumento de que não se enquadraria na hipótese do verbete, não sendo, portanto, prática vedada no sistema jurídico.

A saber: STJ, AgRg no AREsp n. 326.260/SC, Rel. Min. Herman Benjamin, j. em 15-5-2014, DJe de 23-5-2014; TJRS, Ap. Cív. n. 70055555874, Rela. Desa. Maria Claudia Cachapuz, j. em 27-4-2016, DJe de 9-5-2016; TJSP, Reexame Necessário n. 0001056-90.2012.8.26.0279, Rel. Des. Djalma Lofrano Filho, j. em 11-2-2015, DJe de 20-2-2015; TJMG, Ap. Cív. n. 1.0480.06.090095-2/002, Rel. Des. Afrânio Vilela, j. em 7-7-2015, DJe de 13-7-2015.

Como afirma ALEGRE (2008, p. 63) não deixa de ser curioso que justamente os agentes políticos "aqueles que têm a responsabilidade gravíssima de definir os rumos do governo, de decidir a qualidade de vida de um povo inteiro, bem, estes podem nomear parentes à vontade, porque os princípios do art. 37 da CF se aplicam à Administração Pública, não ao Governo!!" (grifo do autor). 


\section{CONCLUSÃO}

Em um contexto de clamor pela reforma de um Judiciário que não podia suprir a alta demanda que the era apresentada, foi promulgada a Emenda Constitucional n. 45/2004, que dentre outras medidas, introduziu à Constituição o art. 103-A, que trata da possibilidade de edição de Súmulas Vinculantes pelo Supremo Tribunal Federal, cujo objetivo é, além de conferir maior segurança jurídica ao Judiciário, também dar maior celeridade na resolução de demandas, por vezes, idênticas.

Dentre os cinquenta e cinco enunciados já editados pelo Supremo Tribunal Federal, destaca-se o de n. 13, não só pela importância do tema, mas por estar baseado essencialmente em princípios constantes na Carta Magna, e não em dispositivos específicos - de onde já parte a controvérsia acerca deles.

$\mathrm{O}$ verbete relaciona-se com o combate à prática do nepotismo. Talvez pela amplitude da matéria, mormente por se estruturar em princípios, o enunciado, ao revés de seu objetivo pacificador de discussões, acabara por fomentar o debate em torno do tema, sem dar ao seu aplicador uma saída que não lhe demande esforço interpretativo - o que contraria a própria razão de existir do instituto que é a celeridade e a segurança jurídica.

As polêmicas que o envolvem iniciam-se, de pronto, com o fato de ter ampliado o vínculo de parentesco afetivo para até o $3^{\circ}$ grau, passando à extensão da hipótese de nepotismo, nesse ponto envolvendo imprecisões não só acerca de termos como "pessoa jurídica", não esclarecido, como do universo em que se pode constatar a ocorrência do nepotismo cruzado. A maior das polêmicas, porém, reside na dúvida acerca da aplicação do enunciado aos agentes políticos.

A redação não os excetua expressamente da aplicação, mas é esse o entendimento do Supremo Tribunal Federal desde a edição da Súmula e, em decorrência dele, também dos demais 
Tribunais pátrios. Aqui, cabe a advertência: embora os Ministros tenham defendido a inaplicabilidade automática do enunciado aos agentes políticos, deixaram claro a possibilidade de reconhecimento do nepotismo também para esses casos.

Por essas razões, e longe de diminuir a importância da Súmula aqui tratada - que embora não firme posicionamento em relação aos aspectos acima desvendados, tem marcante relevância na discussão, e principalmente evolução, do tema nela debatido -, convém destacar os pontos que devem ser esclarecidos pelo Supremo Tribunal Federal, justamente para que se possa dar ainda maior eficácia a tais enunciados.

\section{REFERÊNCIAS}

ALEGRE, José Sérgio Monte. Súmula Vinculante n. 13 (nepotismo), do STF: decifra-me ou te devoro! Revista Brasileira de Direito Público - RBDP. Ano 6, n. 23, out./ dez. 2008, p. 43-77.

ALMEIDA, José Carlos Pacheco de. O nepotismo da administração pública municipal e a Súmula Vinculante no 13 do STF. Revista Síntese Direito Administrativo. São Paulo, v.10, n.117, set./2015, p. 100-123.

ANTONIO, Alice Barreto de. O nepotismo sob a ótica da súmula vinculanten. 3 do STF: críticas e proposições. Revista Brasileira de Direito Municipal - RBDM. Belo Horizonte: Editora Fórum, ano 10, n. 31, jan./mar. 2009, p. 61-84.

ARAKAKI, Allan Thiago Barbosa; ORTIZ Laudson Cruz. Súmula vinculante 13 e o combate ao nepotismo. Revista de Direito Constitucional e Internacional. Ano 19, n. 75, abr-jun. 2011, p. 101-121.

BRASIL. Constituição (1988) Constituição da República Federativa do Brasil. Brasília: Senado Federal, 2016.

. Constituição (1988). Emenda Constitucional n. 45, de 30 de dezembro de 2004. Altera dispositivos dos arts. 5o , 36, 52, 92, 93, 95, 98, 99, 102, 103, 104, 105, $107,109,111,112,114,115,125,126,127,128,129,134$ e 168 da Constituição Federal, e acrescenta os arts. 103-A, 103B, 111-A e 130-A, e dá outras providências. DOU de 31-12-2004. $\overline{1-2002}$.

Lei n. 10.406, de 10 de janeiro de 2002. Institui o Código Civil. DOU de 11-

Lei n. 11.417, de 19 de Dezembro de 2006. Regulamenta o art. 103-A da Constituição Federal e altera a Lei n ${ }^{\circ}$ 9.784, de 29 de janeiro de 1999, disciplinando a edição, a revisão e o cancelamento de enunciado de súmula vinculante pelo Supremo Tribunal Federal, e dá outras providências. DOU de 20-12-2006. 
. Superior Tribunal de Justiça. Agravo Regimental no Agravo em Recurso Especial n. 326.260/SC. Relator Ministro Herman Benjamin, Segunda Turma, julgado em 15-5-2014, DJe de 23-5-2014.

BRASIL. Supremo Tribunal Federal (Org.). Informativo n. 815, de 22 a 26 de fevereiro de 2016. Elaborado a partir de notas tomadas nas sessões de julgamento das Turmas e do Plenário. Disponível em: < http://www.stf.jus.br//arquivo/informativo/documento/ informativo815.htm>. Acesso em: 4 maio 2016.

. Supremo Tribunal Federal. Recurso Extraordinário n. 160.381/SP. Relator Ministro Marco Aurélio, Segunda Turma, julgado em 29-3-1994, DJ de 12-8-1994.

Supremo Tribunal Federal. Recurso Extraordinário n. 579.951/RN. Relator Ministro Ricardo Lewandowski, Tribunal Pleno, julgado em 20-8-2008, DJe de 2410-2008.

. Supremo Tribunal Federal. Agravo Regimental em Medida Cautelar em Reclamação n. 6650/PR. Relatora Ministra Ellen Gracie, Tribunal Pleno, julgado em 1610-2008, DJe de 21-11-2008.

. Supremo Tribunal Federal. Ação Direta de Constitucionalidade n. 12/DF. Relator Ministro Carlos Britto, Tribunal Pleno, julgamento em 20-8-2008, DJe de 1812-2009.

CUNHA, Marize Maria Gabriel de Almeida Pereira da. Os males do nepotismo e a solução dada pela súmula vinculante n. 13 do STF. Fórum Administrativo. Belo Horizonte: Editora Fórum. Ano 10, n. 111, maio de 2010, p. 30-38.

DANTAS, Bruno. Súmula Vinculante: O STF entre a função uniformizadora e o reclamo por legitimação democrática. Revista de Informação Legislativa. Brasília: Serviço de Informação Legislativa, ano 45, n. 179, [julho/setembro] 2008, p. 179-190.

EMPINOTTI, Gabriele. Nepotismo e fiscalização - A súmula vinculante n. 13 e sua eficácia. Fórum Administrativo. Belo Horizonte: Fórum. Ano 13, n. 144, fev. 2013, p. 37-49.

FLORENCIO, Renata Cordeiro Uchoa. Breves apontamentos sobre o Common Law e a aplicação do sistema de precedentes no Brasil. Publicações da Escola da AGU. Brasília: EAGU, ano III, n. 12, set./out. 2011, p. 337-362.

MAGALHÃES, Bruno Barata. Não há interpretação exata para a súmula vinculante 13.Publicado em 10 de setembro de 2008. Disponível em: <http://www.conjur.com. br>. Acesso em: 14 jun. 2013.

MARTINS, Alan. A súmula vinculante perante o princípio constitucional da tripartição dos poderes.Revista Síntese de Direito Civil e Processual Civil. Porto Alegre: Síntese, ano VI, n. 35, maio-jun. 2005, p. 38-47.

MELLO, Celso Antônio Bandeira de. Curso de direito administrativo. 32. ed. rev. e atual. São Paulo: Malheiros Editores, 2015.

MINAS GERAIS. Tribunal de Justiça. Apelação Cível n. 1.0480.06.090095-2/002. Relator Desembargador Afrânio Vilela, 2a Câmara Cível, julgamento em 7-7-2015, DJe de 13-7-2015.

OLIVEIRA, George Felício Gomes de. Da análise da súmula vinculante 13 do Supre- 
mo Tribunal Federal: alcance, precedentes e motivos determinantes da norma que veda a prática de nepotismo no Brasil. Revista dos Tribunais. São Paulo: Editora Revista dos Tribunais. Ano 98, vol. 890, dez 2009, p. 9-32.

PERTENCE, Sepúlveda. Pertence: Efeito vinculante é prioritário. Jornal da Anpar, [s. 1.], p. 9-10, 07/10, 1996. Disponível em:<http://www.stf.jus.br $>$. Acesso em: 5 maio 2016.

RIO GRANDE DO SUL. Tribunal de Justiça. Apelação Cível $n$. 70055555874 . Relatora Desembargadora Maria Claudia Cachapuz, Segunda Câmara Cível-Serviço de Apoio Jurisdição, julgamento em 27-4-2015, DJe de 9-5-2016.

SÃO PAULO. Tribunal de Justiça. Reexame Necessário n. 0001056-90.2012.8.26.0279. Relator Desembargador Djalma Lofrano Filho, 13a Câmara de Direito Público, julgamento em 11-2-2015, DJe de 20-2-2015.

SIFUENTES, Mônica. Súmula vinculante : um estudo sobre o poder normativo dos tribunais. São Paulo, Saraiva, 2005.

STRECK, Lenio Luiz. Súmulas no direito brasileiro: eficácia, poder e função: a ilegitimidade constitucional do efeito vinculante. 2. ed. rev. ampl. Porto Alegre: Livraria do Advogado, 1998

Artigo recebido em 15/06/2016

Artigo aprovado em 10/08/2016 